\title{
Russia and the WTO: The "Gravity" of Outsider Status
}

\author{
BOGDAN LISSOVOLIK AND YAROSLAV LISSOVOLIK*
}

With China's accession to the WTO in 2001, Russia is by far that organization's most prominent nonmember. This paper applies the gravity model to gauge whether this "outsider" status has been affecting Russia's export structure. On the basis of cross-section and panel regressions for 1995-2002, we find that Russian exports to WTO members have fallen short of the model's predictions. The paper discusses possible explanations of this result, including Russia's exclusion from various WTO procedures, although own-export restrictions could have a similar effect. The model points to Russia's further trade reorientation toward WTO members after a putative accession. Our results also prompt some ideas that may clarify the recent empirical controversy over the WTO's overall role in promoting trade. [JEL F14, F18]

he role of the World Trade Organization (WTO) in international trade has recently come under increased scrutiny. In a provocative study, Rose (2002) concluded - on the basis of a gravity model - that the effect of the WTO on trade was insignificant. This result was disputed by several authors. ${ }^{1}$ In particular, Subramanian and Wei (2003) employed an augmented specification of the gravity model to estimate the relationship between trade and WTO membership. These

*Bogdan Lissovolik is a Senior Economist in the European Department of the IMF. Yaroslav Lissovolik is a Chief Economist with United Financial Group in Moscow and was an Advisor to Russia's Executive Director at the IMF when this paper was written. The authors would like to thank Hans Peter Lankes, Nienke Oomes, David Owen, Andrew Rose, Emil Stavrev, Patrizia Tumbarello, Bert Van Selm, an anonymous referee, and participants in the seminar at the IMF's European Department for helpful comments and suggestions. Tom Walter provided valuable editorial input, and Arlene Tayas excellent logistical support.

${ }^{1}$ See Rose (2005). 
authors argued that the organization strongly promotes trade, although with considerable asymmetries across sectors and groups of countries. In particular, WTO liberalization appears to be more useful to members than to nonmembers, although the latter also could benefit somewhat from the spillover effect of expanding global trade. Rose has countered, however, that these asymmetries are not central to the WTO's overall role, and thus the debate continues.

This paper uses a gravity model to evaluate the impact of the WTO on the trade of Russia - currently the largest nonmember. There are several reasons for the single-country focus. First, it partly gauges the insights of the "multicountry" gravity models, since these should, to a certain extent, apply to large countries with reasonably diversified trade flows. Second, it assesses the WTO-related issues from a national perspective, which is, in practice, a key focus of most policy decisions. Third, Russia's case is particularly important because of its size and the fact that its accession negotiations provide a reference point for some other nonmember countries (notably in the Commonwealth of Independent States (CIS)) involved in a similar process. Finally, Russia's WTO accession has been a very contentious topic, both in terms of its domestic political economy and with respect to entry conditions demanded by some WTO members.

Our main conclusion is that the impact of Russia's accession to the WTO on the structure and possibly the level of trade may be quite significant and could be much higher than current estimates. As a first step, we find cross-section and panel data evidence that, on average (after adjusting for the customary gravity model and country-specific effects), Russia's exports to the WTO countries underperformed its exports to other countries in 1995-2002. These results are somewhat surprising in light of both the general trade-promoting view of the WTO and the overwhelming casual evidence of Russia's trade reorientation toward the more advanced developed and developing countries, all of which are or have recently become WTO members.

As a second step, we explore the possible reasons for this empirical result, which include (1) Russia's nonparticipation in WTO procedures, (2) Russia's own export restrictions, (3) possible model specification and data caveats, (4) structural path dependence in Russia's exports, and (5) Russia's comparative advantage in bargaining with WTO nonmembers. The first two factors come out as more plausible and consistent with the stylized facts: It appears that, with WTO accession (which will relieve trade restrictions), Russia would further reorient its trade in line with the gravity model. If so, the magnitude of the trade-related benefits from joining the WTO appears quantitatively large in the long term, although the precise parameter estimates must be interpreted with caution, given the partial nature of the model and certain data problems.

Finally, we discuss how our results might help shed some light on the current empirical controversy over the WTO's overall role in influencing trade. We conclude that, while the WTO exhibits some trade-promoting features, the asymmetry between members and nonmembers also may constrain trade and may obscure econometric evidence of the WTO's role in multilateral models. The reason is that a large country like Russia may be a local "center of gravity" for some non-WTO members, and the customary controls of the gravity model do not eliminate this effect fully in multilateral WTO studies. 
Figure 1. Russia's Exports in 1990-2003

(US\$ billion)

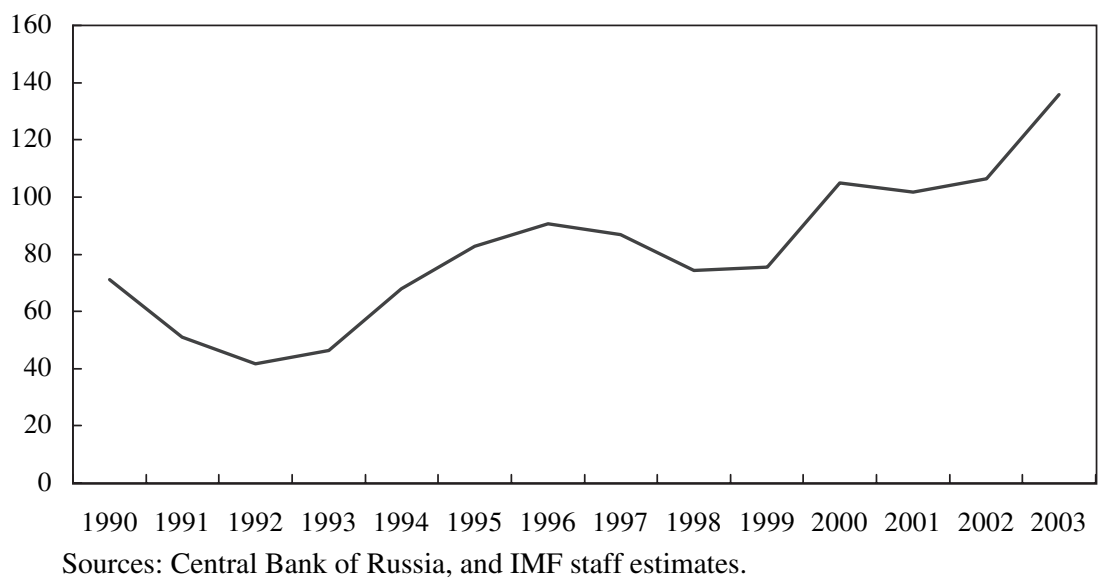

\section{Russia's Evolving Integration into the World Trading System} Trade Developments

After proclaiming independence in late 1991, Russia embarked on a difficult transition from central planning to a market economy. The key dimension of this transition has concerned the opening up and integration of Russia's economy into the world economy, with the primary focus on trade's role in unleashing incentives in line with the fundamental principle of comparative advantage. This process seemed critical, as much of external trade of the socialist bloc had not been based on market principles but reflected priorities imposed by political and ideological factors. Thus, export and import flows had been heavily concentrated in the former socialist economies and involved various forms of explicit or implicit subsidization. The sudden change in the policy course was exacerbated by the severe economic dislocation of the early 1990s, with further significant effects on the extent, direction, and time profile of adjustment in the external trade sector.

Russia experienced large shifts in levels and structure of external trade during the transition period. In terms of levels, the shock of Soviet disintegration caused a trade implosion in 1991-92 (see Figure 1); this was followed by a steady rebound in 1993-2003, except for a brief slippage in 1997-98.

The significant structural changes in Russia's trade occurred mostly in the early 1990s. The main geographical trend was a reorientation away from the former socialist economies toward more advanced market economies (see Table 1). Trade with the former socialist economies contracted very abruptly, as the value of Russia's exports to those countries decreased by more than half in 1991 alone. $^{2}$

${ }^{2}$ See Granville (1995). However, pre-1994 data on Russia's trade are highly imperfect for a variety of reasons, including very weak compilation capacity and distorted valuation. 
Table 1. Geographical Structure of Russia's Exports in 1990, 1995, and 2002 (In percent of total exports)

$\begin{array}{lccr} & 1990 & 1995 & 2002 \\ \text { Commonwealth of Independent States } & 64.0 & 18.5 & 14.6 \\ \text { European Union } & \ldots & 33.6 & 34.9 \\ \text { Other Former COMECON }^{1} & 15.5 & 11.0 & 10.7 \\ \text { United States } & \ldots & 6.6 & 6.1 \\ \text { China } & \ldots & 4.4 & 6.3\end{array}$

Sources: IMF, Direction of Trade Statistics; Daviddi and Espa (1996) for the 1990 data.

${ }^{1}$ Refers to Bulgaria, Cuba, former Czechoslovakia, former East Germany, Hungary, Poland, Romania, Mongolia, and Vietnam.

Since the mid-1990s, however, changes in the geographical composition have not been very large. In the end, Russia's exports remained geographically diversified, at least compared with those of the CIS countries. Thus, the share of Russia's three main export markets in total exports was 23 percent in 1995, compared with between half and two-thirds for other CIS countries (see Elborgh-Woytek, 2003). In 2001, this figure stood at 22 percent for Russia, compared with a 31-65 percent range for other CIS countries.

The commodity composition of trade also has changed significantly compared with that of socialist times, particularly on the export side, with a reduction in machinery exports accompanying a steady expansion in shipments of energy and, to a lesser extent, semiprocessed goods (metals and chemicals). For example, the share of machinery in Russia's exports to non-CIS countries fell from 18 percent in 1990 to 7 percent in 1993 (Daviddi and Espa, 1996). To some extent, these changes reflected the expected market-based pressure to downsize low or negative valueadded activities. While there were further changes in the commodity composition

Table 2. Sectoral Structure of Russia's Exports in 1995 and 2002 (In percent, current U.S. dollar value terms)

\begin{tabular}{lrr} 
& 1995 & 2002 \\
Agricultural products & 3.3 & 2.6 \\
Minerals & 42.0 & 55.2 \\
Chemical industry products & 9.9 & 7.0 \\
Wood, pulp, and paper & 5.6 & 4.6 \\
Textiles & 1.5 & 0.8 \\
Metals and precious stones & 26.1 & 18.6 \\
Machinery and transport equipment & 9.9 & 9.5 \\
Other & 1.7 & 1.7 \\
\multicolumn{1}{c}{ Source: Goskomstat of Russia. } & &
\end{tabular}


of exports between 1995 and 2002 (see Table 2), they were much less pronounced than in the early 1990s.

These trade-related developments appear to have had a sizable impact on the key macroeconomic and structural dimensions of Russia's transition. On the macroeconomy, the trade contraction greatly exacerbated the early output decline and "disorganization" (see Blanchard and Kremer, 1997), while the subsequent start of trade recovery preceded the stabilization of output (see Figure 2), and that of the exchange rate, and prices in the mid-1990s. The 1998 currency crisis was in no small measure triggered by adverse shocks to Russia's exports, while the post1998 recovery relied on the reversal of those shocks in conjunction with the substantial expansionary impact of the real depreciation of the ruble. ${ }^{3}$ Regarding structural issues, trade has not only subjected enterprises to competitive pressures and world price signals but also helped keep in check barter and other forms of a noncash economy, which had plagued Russia's transformation for most of the 1990s.

Despite its largely beneficial effect in terms of market-based adjustment, the role of foreign trade in Russia's economy has been constrained by domestic and external policy decisions. Domestically, the decisions reflected discretionary government interference, with more than occasional administrative actions at federal and local levels against the principles of free trade. A case in point is various export restrictions or bans imposed by local governments to protect the supply of essential products during the 1990s. Another example is federal government decisions to tax or restrict exports of energy products more heavily starting in 1999. Whatever the merit of some of these steps, they caused concern over policy reversals in the absence of a comprehensive strategy and framework for such decisions. Externally, the key problem concerned the substantial remaining restrictions on Russia's exports by industrialized and some developing countries, which have mostly affected semiprocessed products such as metals and chemicals. These policies may explain the evidence that the bulk of trade-related structural change occurred in the early 1990s but slowed substantially thereafter.

\section{The WTO Entry Debate}

Russia's accession to the WTO has emerged as a key step for further marketoriented reform (see Lissovolik and Liventsev, 2002). ${ }^{4}$ On the one hand, this accession could harmonize Russia's domestic legislation and practices with those of its major trading partners. On the other hand, it would remove the main remaining obstacles to Russia's exports to WTO members, amplifying the substantial gains from trade that Russia has already been able to generate. The unused potential for further trade reorientation is illustrated by the fact that Russia's exports to the WTO accounted for "only" about 80 percent of its total exports in 2002 (Figure 3),

\footnotetext{
${ }^{3}$ See Owen and Robinson (2003) for an overview of macroeconomic and structural developments in Russia.

${ }^{4} \mathrm{~A}$ short chronology of Russia's ongoing WTO accession process is provided in Appendix Table A.1.
} 
Figure 2. Growth in Real GDP and Real Exports in 1990-2003 (In percent)

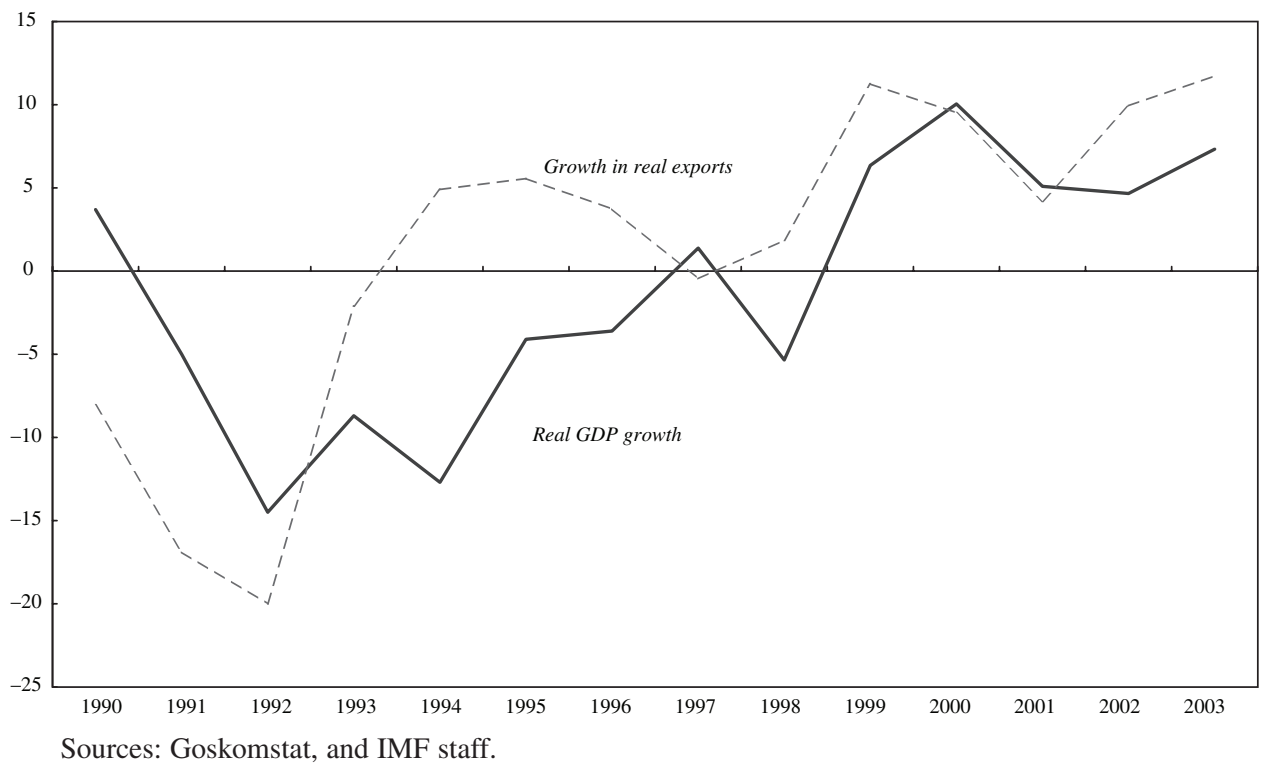

compared with the 95 percent share of WTO members in world trade. Furthermore, the share of Russia's exports to WTO countries that became members of the organization in 1995 hardly changed in the period 1995-2002, with the growth in the share of exports directed to all WTO countries largely accounted for by the increase in WTO membership. However, despite these arguments and the procla-

Figure 3. Share of Russia's Exports to WTO Countries in Its Total Exports (In percent)

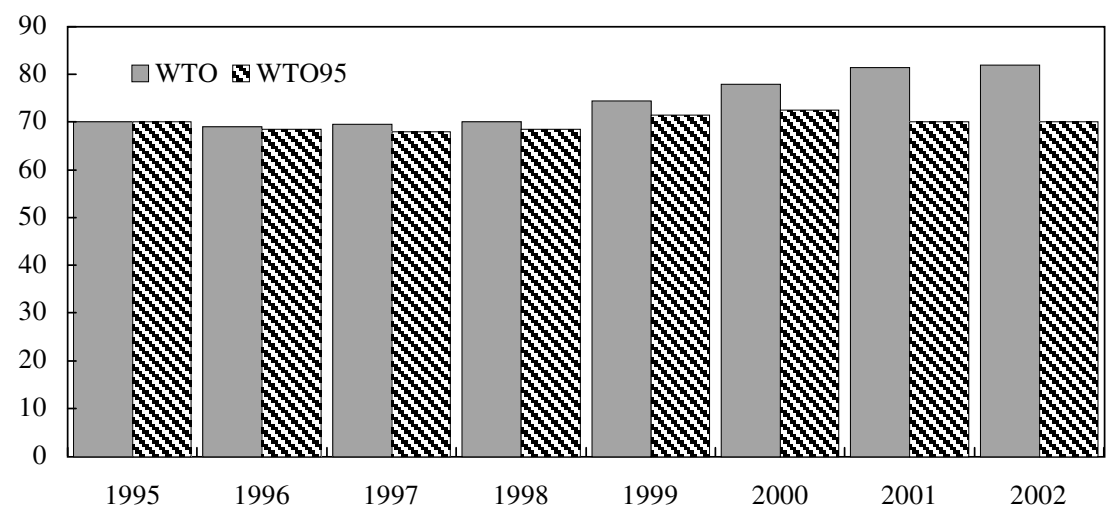

Source: IMF, Direction of Trade Statistics.

Note: the WTO series shows the share of Russia's exports to all WTO members in each year, while the WTO-95 series gives the same indicator only for those countries that were WTO members by the end of 1995. 
mation of WTO entry as Russia's key policy priority, the debate on the benefits of Russia's membership has become more ambiguous lately, causing substantial delays in the already protracted accession process.

The uncertainty over Russia's gains from WTO membership is based on several factors. First, the past few years have seen less optimism over the benefits and prospects of free trade, both around the world (following the well-known events in Seattle and Cancun) and within Russia. Second, domestic opponents of Russia's WTO entry have argued that additional gains from membership would be limited, since the country already enjoys most favored nation (MFN) status with many WTO members, and some advanced countries have accorded preferential treatment to Russia under the Generalized System of Preferences (GSP). Third, there have been concerns over asymmetric treatment, as Russia's concessions (in the form of lower tariffs) on imports and a possible short-term output contraction would far outweigh any benefits for its exports. Fourth, some of the conditionality demanded during the accession process-particularly on the liberalization of domestic energy prices-has been widely unpopular because of the perceived economic and social consequences inside Russia. Finally, there has been a determined opposition to WTO entry from some sectoral lobbies, as well as from the ideological opponents of "economic liberalism."

The advocates of WTO accession have not been short on counterarguments. They point to gains from trade liberalization as largely accruing to WTO members, benefiting nonmembers much less. Importantly, some of the effects of WTO membership may not be explicitly embedded in the lower tariff levels but concern intangibles (such as access to the dispute settlement body of the WTO) that are important for establishing a level playing field with WTO members. Thus, Russia's outsider status not only deprives it of automatic MFN treatment but also of the option of defending its interests through the institutional framework of the WTO. Another counterargument is that the possible short-term losses from import competition may be manageable in light of longer-term efficiency gains. The latter would likewise result from the level playing field facilitated by appropriate promarket structural reforms and by constraints on vested interests.

While WTO accession has proved to be a bone of contention, there is a relative dearth of quantitative evidence to help resolve or anchor this debate. Russia's accession to the WTO has been the subject of a number of studies, but they have had fairly disparate frameworks and the results have varied. The more comprehensive studies have generally focused on the output implications of accession. For example, the Russian Academy of Sciences and the National Investment Council (RAS, 2002) used an input-output model to explore the consequences of accession-related reductions in import duties for sectoral and regional output dynamics. The overall output effect was estimated at 1 percent of GDP. Another study by Tarr, Jensen, and Rutherford (2002) employed a computable general equilibrium (CGE) model, which, in addition to changes in import duties, also estimated the effects of foreign investment and concluded that the latter was likely to account for up to 70 percent of Russia's benefits from WTO accession. On this basis, GDP gains were estimated to range from 3 percent in the medium term to about 25 percent in the longer term. 
A major underlying problem with these estimates has been the lack of a reasonably comprehensive projection of the effect of accession on Russia's exports, which may be of primary importance both for the derivation of the output effects and in its own right. Alekseev, Tourdyeva, and Yudaeva (2003) briefly explore this issue in a CGE model, with the assumption that Russia's export competitiveness would be enhanced with lower import duties. Their study yields a broad-based but very modest estimate of a 0.9 percent export expansion. However, the calculation disregards the likelihood that Russia's exports may already be constrained as a consequence of nonmembership. Berglöf and others (2003) put this shortfall at $\$ 3$ billion, or about 3 percent of Russia's total exports, based on an assessment of actual restrictions on Russian exports across sectors. Still, one may argue that this effect could be very different in the longer term, as the economy adjusts to the improved market access. We know of no studies that explore such a general equilibrium effect within a model of Russia's external trade, and we intend to fill that gap in what follows. ${ }^{5}$

\section{Econometric Specification and Data}

\section{Model}

The gravity model has been one of the notable successes in empirical economics (see Anderson and van Wincoop, 2003). Its applications have by now become standard for the evaluation of various issues in trade, migration, investment, currency unions, and so on. In particular, it has served as both an alternative and a complement to the CGE models (Greenaway and Milner, 2002). It has recently been used to assess the effect of the WTO on multilateral trade patterns, notably by Rose (2002) and Subramanian and Wei (2003), who evaluated the sign and magnitude of the "WTO dummy" after controlling for the customary gravity effects. We will employ a Russia-centered gravity model to evaluate Russia's trade determinants and patterns, with particular attention to the role of the WTO. ${ }^{6}$

The standard gravity model specification relates total trade turnover or exports/ imports as a dependent variable to distance and GDP as independent variables. Most such models also include additional independent variables, such as population, GDP per capita, and dummy variables denoting borders, islands, and former colonies, as well as membership in free trade areas (FTAs), currency unions, and so on. Our basic model is given by

$$
\begin{aligned}
\operatorname{Ln}\left(X_{i t}\right)= & \ln \left(D_{i}\right)+\ln \left(Y_{r t} * Y_{i t}\right)+\ln \left(y_{r t} * y_{i t}\right) \\
& + \text { USSR }_{i}+\text { COMECON }_{i}+\text { EAEC }_{i}+\text { BORDER }_{i}+\text { WTO }_{i t}+\mu_{i t},
\end{aligned}
$$

${ }^{5}$ Dean and Eremenko (2003) used gravity model simulations for Ukraine, concluding that there would be no measurable improvement of its market access in the event of WTO accession. However, their model did not explicitly include a WTO-related variable.

${ }^{6}$ The gravity model has already been used for Russia and the former Soviet Union in several studies, notably by Gros and Steinherr (1995) and van Selm (1997). That research pointed to the high predictive power of the model with respect to the intra-Soviet trade flows. 
where $X$ stands for Russia's exports to country $i$ at time $t ; D$ is the distance between Russia and country $i$; the subsequent two terms denote the products of Russia's and the partner's GDPs and GDPs per capita, respectively; USSR and COMECON are dummy variables denoting the partner country's former status as a Soviet republic or a former member of the Council of Mutual Economic Assistance; $E A E C$ stands for the countries forming the Eurasian Economic Community; and BORDER denotes the existence of a common border with Russia. The inclusion of these variables allows us to control for as many natural causes of trade as possible and search for effects of the WTO dummy variable (reflecting the partner country's membership in the WTO) on the residual. To check the robustness of the basic results, more independent variables common to the literature will be added to the basic regression; in particular, those reflecting trade regimes and restrictions (i.e., tariffs and the GSP), as well as those pertaining to country and sectoral asymmetries, identified by Subramanian and Wei (2003) as important for assessing the general impact of the WTO on trade.

We define distances between Russia and its trading partners as the "great circle" between Moscow and the respective capitals of the partner countries. Given Russia's size, there may be a problem with this definition; for example, Morocco is deemed closer to Russia than China is, even though Russia shares an extensive border with the latter. Gros and Steinherr (1995) resolved this problem by splitting Russia's economic space into several macroregions, whose distances to Russia's trading partners were estimated separately. In what follows, we confine ourselves to adding a dummy variable for bordering countries, which in part addresses the distortion of distance measurement. We believe that our capital-distance-correctedfor-border approach may be much more reasonable than the alternative (smallest distance between the borders), given that much of Russia's economic potential is heavily concentrated in the European part of the country, of which Moscow is the approximate center.

Regarding global trading arrangements, our analysis focuses narrowly on the role of the WTO proper, leaving the effects of its predecessor-the General Agreement on Tariffs and Trade (GATT)—outside the scope of this study. This is largely because the WTO was created only three years after Russia's independence and about the time when Russia's trade flows were beginning to be guided mostly by market forces. There are also important differences between the WTO and the GATT that may rationalize their separate treatment in empirical studies (although much of the existing empirical literature has ignored them): (1) the WTO is an intergovernmental organization (while the GATT was essentially a set of rules) with an institutional framework and a greater role of multilateral agreements, (2) the WTO dispute settlement system appears to be significantly more efficient than the system under the GATT, and (3) the WTO has a much wider coverage of trade issues.

Our specification of the gravity model differs in several ways from that of most models employed in the related literature, reflecting the particular aims and constraints of our exercise. First, we confine the data set to the post-Soviet period of 1995-2002, thereby skipping the statistical chaos in the Russian export series of the early 1990s. However, this comes at the cost of significantly reducing the number of periods for time-series analysis. Second, the model investigates only 
Russia's pairwise trade with other countries, as opposed to the multilateral setup of most gravity models. This country-centered specification of the gravity model is not unusual (see Hufbauer and Oegg, 2003) and allows us to focus on idiosyncratic patterns of Russia's foreign trade through a more precise modeling of the countryspecific parameters. However, we should be cautious about generalizing some of our conclusions on the effects of WTO membership, since Russia's specific characteristics may impart a bias or complicate the interpretation of the WTO variable.

\section{Data}

While existing data sets on the gravity model (most notably that of Andrew Rose, posted on his website-see Rose, 2005) served as a guide, the bulk of the data have been compiled from various sources. The data set spans a period of eight years from 1995 to 2002 and encompasses 171 countries, most of which are WTO members, including the recent entrants (see Table 3). In order to account for data imperfections in the course of the sensitivity analysis, five countries were excluded for reasons of likely measurement error and incomplete observations. ${ }^{7}$ The exact definitions of the variables are presented in Appendix Table A.2. The data on exports are derived from the IMF's Direction of Trade Statistics, with the occasional gaps covered by Russia's customs statistics. The sectoral dummy variables (for the metals and oil sectors) were derived with the help of data from the Customs Committee of the Russian Federation. The information on world population was obtained from the United Nations and from the U.S. Census Bureau. GDP figures across countries are taken from the IMF's World Economic Outlook (WEO) database. The data on distances from world capitals to Moscow were derived from computer software that is readily available on the website of the U.S. Department of Agriculture. All regressions were performed using Stata 8.0.

As recognized by Rose (2002), the data on the GSP are imperfect, although the United Nations Conference on Trade and Development (UNCTAD) has been making an effort to compile and update the data on the beneficiaries of GSP regularly. One such database posted on the official UNCTAD website ${ }^{8}$ contains a list of countries that granted Russia GSP status as of June 1, 2001. Of the 19 countries that have accorded GSP status to Russia, 15 are members of the European Union; the 4 remaining countries are Canada, the Czech Republic, the Slovak Republic, and the United States.

Data on Russia's exports in 1995-2002 exhibit significant volatility across time, with exports to some countries in Africa and Latin America emerging only toward the second half of the period. Owing to the conversion of exports into natural logarithms, the observations denoting zero exports to trading partners were treated as missing by Stata, thereby significantly reducing the overall number of observations in the panel data set. To check for this problem, we also transform the

\footnotetext{
${ }^{7}$ Including the estimates for these countries and territories (Bermuda, Cuba, Iraq, Democratic People's Republic of Korea, and Serbia and Montenegro) does not alter the statistical significance of the results or their qualitative nature.

${ }^{8}$ See http://www.unctad.org/Templates/Page.asp?intItemID=1418\&lang=1.
} 
Table 3. Annual Increase in WTO Membership, 1995-2002

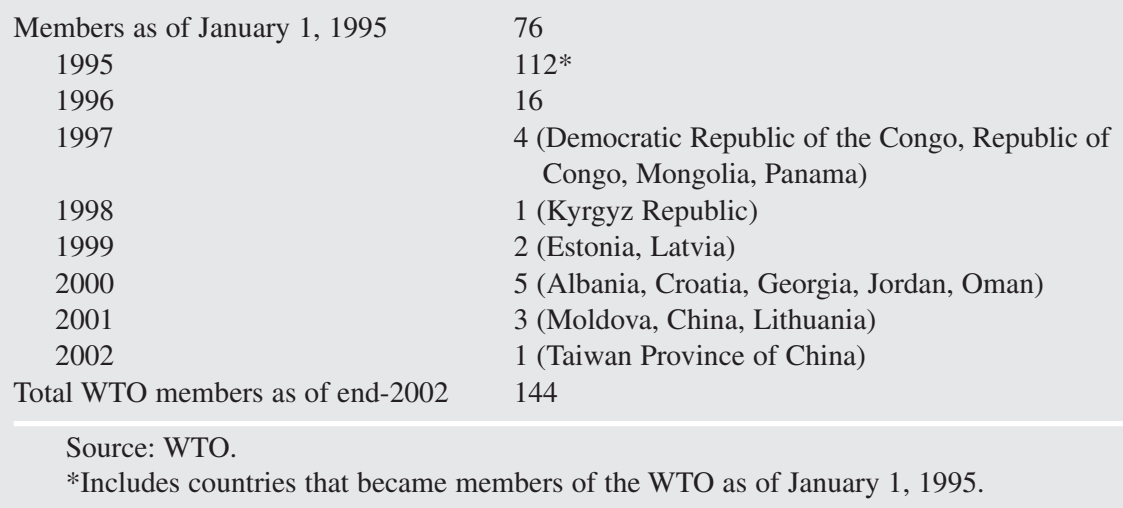

underlying data in various ways: by adding 1 to the number under the logarithm, by assigning negligible values to the missing observations, or by averaging observations across periods. As reported below, these changes did not have a significant effect on the basic regression results.

\section{Econometric Results}

To shed light on the factors behind Russia's export performance, we run several sets of gravity model regressions. We also explore various modifications to the underlying model to check the robustness of our results.

\section{Cross-Section Regressions}

Table 4 presents the main cross-section results, which are tabulated as sequential independent regressions with each of the year-specific WTO dummies for the 1995-2002 period. The outcomes appear reassuring. The gravity model seems to fit Russia's export data quite well, as can be seen from the high $R$-squared, averaging some 70 percent across the regressions for different years. Distance and output coefficients are all significant, with signs and magnitude similar to those of other applied gravity models. In particular, the coefficient on distance is generally slightly lower than -1 , while the sum of coefficients on output and output per capita is close to unity. The former Soviet Union and COMECON dummy variables are also highly positive and significant. The dummies for common border countries and the EAEC also are of the right sign but are generally not significant, at 5-10 percent levels.

Interestingly, the WTO coefficient is always negative, although in most cases (with the exception of 1996) it is statistically insignificant at the 5 percent level. At the same time, the coefficient is close to being significant at the 10 percent level for most years, while truly negligible only for 1998 data. However, 1998 was the year of severe macroeconomic crisis in Russia and thus could possibly reflect 
Table 4. Cross-Country Ordinary Least Squares (OLS) Regressions, 1995-2002 (Regressand: Russia's exports; standard errors below)

\begin{tabular}{|c|c|c|c|c|c|c|c|c|c|c|}
\hline & \multirow[b]{2}{*}{1995} & \multirow[b]{2}{*}{1996} & \multirow[b]{2}{*}{1997} & \multirow[b]{2}{*}{1998} & \multirow[b]{2}{*}{1999} & \multirow[b]{2}{*}{2000} & \multirow[b]{2}{*}{2001} & \multirow[b]{2}{*}{2002} & \multicolumn{2}{|c|}{ Annual Means } \\
\hline & & & & & & & & & WTO-95 & WTO-96 \\
\hline \multirow[t]{2}{*}{ WTO } & -0.55 & -1.19 & -0.45 & 0.00 & -0.55 & -0.55 & -0.54 & -0.54 & -0.76 & -0.98 \\
\hline & 0.38 & 0.36 & 0.36 & 0.28 & 0.34 & 0.31 & 0.32 & 0.43 & 0.32 & 0.34 \\
\hline \multirow[t]{2}{*}{ Log distance } & -0.98 & -1.22 & -0.96 & -1.01 & -0.96 & -1.35 & -1.35 & -1.63 & -1.38 & -1.34 \\
\hline & 0.20 & 0.20 & 0.21 & 0.18 & 0.24 & 0.21 & 0.22 & 0.29 & 0.24 & 0.24 \\
\hline \multirow{2}{*}{$\begin{array}{l}\text { Log product } \\
\text { real GDP }\end{array}$} & 0.72 & 0.75 & 0.65 & 0.64 & 0.84 & 0.88 & 0.91 & 1.02 & 1.00 & 0.99 \\
\hline & 0.10 & 0.08 & 0.08 & 0.07 & 0.08 & 0.07 & 0.07 & 0.09 & 0.08 & 0.07 \\
\hline \multicolumn{11}{|l|}{ Log product } \\
\hline \multirow{2}{*}{$\begin{array}{l}\text { real per } \\
\text { capita GDP }\end{array}$} & 0.11 & 0.38 & 0.26 & 0.18 & 0.06 & 0.08 & 0.07 & -0.01 & 0.14 & 0.15 \\
\hline & 0.11 & 0.10 & 0.10 & 0.08 & 0.10 & 0.09 & 0.09 & 0.12 & 0.10 & 0.10 \\
\hline \multirow{2}{*}{$\begin{array}{l}\text { Common } \\
\text { border }\end{array}$} & 0.11 & 0.23 & 0.40 & 0.39 & 0.59 & 0.44 & 0.56 & 0.30 & 0.23 & 0.18 \\
\hline & 0.45 & 0.45 & 0.47 & 0.40 & 0.58 & 0.51 & 0.53 & 0.69 & 0.60 & 0.60 \\
\hline \multirow[t]{2}{*}{ USSR } & 2.01 & 1.82 & 2.17 & 1.91 & 1.93 & 1.51 & 1.77 & 1.80 & 2.13 & 2.00 \\
\hline & 0.62 & 0.59 & 0.60 & 0.49 & 0.70 & 0.62 & 0.63 & 0.82 & 0.72 & 0.72 \\
\hline \multirow[t]{2}{*}{$\mathrm{COMECON}^{1}$} & 2.14 & 2.66 & 2.62 & 2.00 & 2.36 & 2.22 & 2.18 & 1.98 & 2.22 & 2.30 \\
\hline & 0.50 & 0.49 & 0.52 & 0.43 & 0.62 & 0.54 & 0.56 & 0.73 & 0.61 & 0.60 \\
\hline \multirow[t]{2}{*}{ EAEC } & 0.89 & 0.95 & 0.73 & 0.89 & 0.96 & 1.20 & 1.06 & 0.94 & 1.10 & 1.09 \\
\hline & 0.76 & 0.76 & 0.80 & 0.69 & 1.00 & 0.88 & 0.91 & 1.20 & 1.04 & 1.03 \\
\hline \multirow[t]{2}{*}{ Constant } & 5.93 & 7.06 & 5.65 & 6.42 & 4.70 & 7.74 & 7.04 & 8.51 & 6.18 & 6.10 \\
\hline & 1.89 & 1.89 & 1.94 & 1.61 & 2.21 & 1.93 & 2.01 & 2.67 & 2.29 & 2.27 \\
\hline$R$-squared & 0.62 & 0.75 & 0.70 & 0.76 & 0.69 & 0.76 & 0.76 & 0.69 & 0.76 & 0.77 \\
\hline \multicolumn{11}{|l|}{ Number of } \\
\hline observations & 92 & 103 & 117 & 123 & 153 & 153 & 146 & 155 & 168 & 168 \\
\hline$F$-test & 16.97 & 35.23 & 31.39 & 45 & 40.19 & 57.6 & 53.5 & 40.97 & 63.86 & 65.12 \\
\hline
\end{tabular}

some specific factors. The persistently negative sign on the WTO dummy basically means that, after controlling for the gravity factors, Russia systematically tended to export more to non-WTO countries than to WTO countries.

To even out year-specific idiosyncrasies, we run a cross-section regression on the anual means of the model's variables (last two columns of Table 4). These "core" regressions include the dummy variables reflecting WTO membership at end-1995 and at end-1996, the last year when changes in membership took place on a significant scale. The basic "gravity" coefficients on distance and total GDP continue to be highly significant and appropriate in sign and magnitude, as are the dummies on the former Soviet Union and COMECON. The WTO dummy becomes statistically significant and numerically larger, whereas those that denote the customs union and the Russia-bordering countries do not, possibly because their effect is already captured by the strongly significant variable reflecting the role of the former Soviet Union.

The results of the regressions on annual means hold for exports as the dependent variable in the regression but also for the overall trade turnover. The WTO 
coefficient remains statistically significant and negative in all those regressions. The absolute value of the distance coefficient is smaller than with exports as the dependent variable, whereas the opposite is true for the GDP coefficient. Additionally, the results were robust to different gravity model specifications (Linnemann, 1966; Bergstrand, 1985; and Wang and Winters, 1992), some of which included single-country population and GDP variables separately (instead of per capita GDP or a product of country-pair GDPs). In all such specifications, the statistical significance of the negative WTO coefficient remained largely intact.

\section{Pooled Regressions}

Despite their widespread use in the academic literature, cross-section gravity regressions have a number of limitations compared with full-fledged panel data regressions. First, they entail a loss in the number of observations that could be used in the regression, thereby possibly affecting the robustness of the results. Second, they disregard time variation in the data and thus may result in inconsistent estimates (Matyas, 1997). Third, they do not fully answer some policy questions of interest; for example, regarding (1) any effects of the model on the direction of change in trade flows or (2) a trade effect of a Russian partner country's joining the WTO.

As a further step, ordinary least squares (OLS) pooled regressions were performed on all of the observations of the data set for 1995-2002. Compared with the cross-section regressions, the WTO dummy becomes time varying, so instead of the period-specific WTO dummies, we construct a single WTO dummy variable. The results (see first column of Table 5) do not appear to differ much from those of cross-section regressions, with the WTO coefficient negative and statistically significant. Also, the customs union and border dummies become statistically significant at the 5 percent level, which is to be expected with the large increase in the number of observations.

This pooled regression was tested through several robustness checks, none of which mattered for the basic results, including the WTO variable. To account for the possible correlation of country observations over time, we also used robust standard errors (column 2 of Table 5). We also experimented with the inclusion or exclusion of alternative country-specific observations (columns 3-6 and 8), as well as with the quadratic gravity term (column 7).

In sum, the pooled regressions confirm the results of cross-section data but do not appear to add much new qualitative insight. This may indicate that the main driving force for the results is heterogeneity across countries. However, while pooled regressions appear to reinforce cross-sectional results (including on the role of the WTO), this method imposes identical coefficients across countries and thus may induce misspecification. A more sophisticated framework would be helpful to check the robustness of the results, including by disentangling the time-invariant and country-specific effects.

\section{Time, Fixed, and Other Effects}

Table 6 presents panel data regressions with time effects. The results remain very similar to those for pooled regressions and withstand a number of robustness 


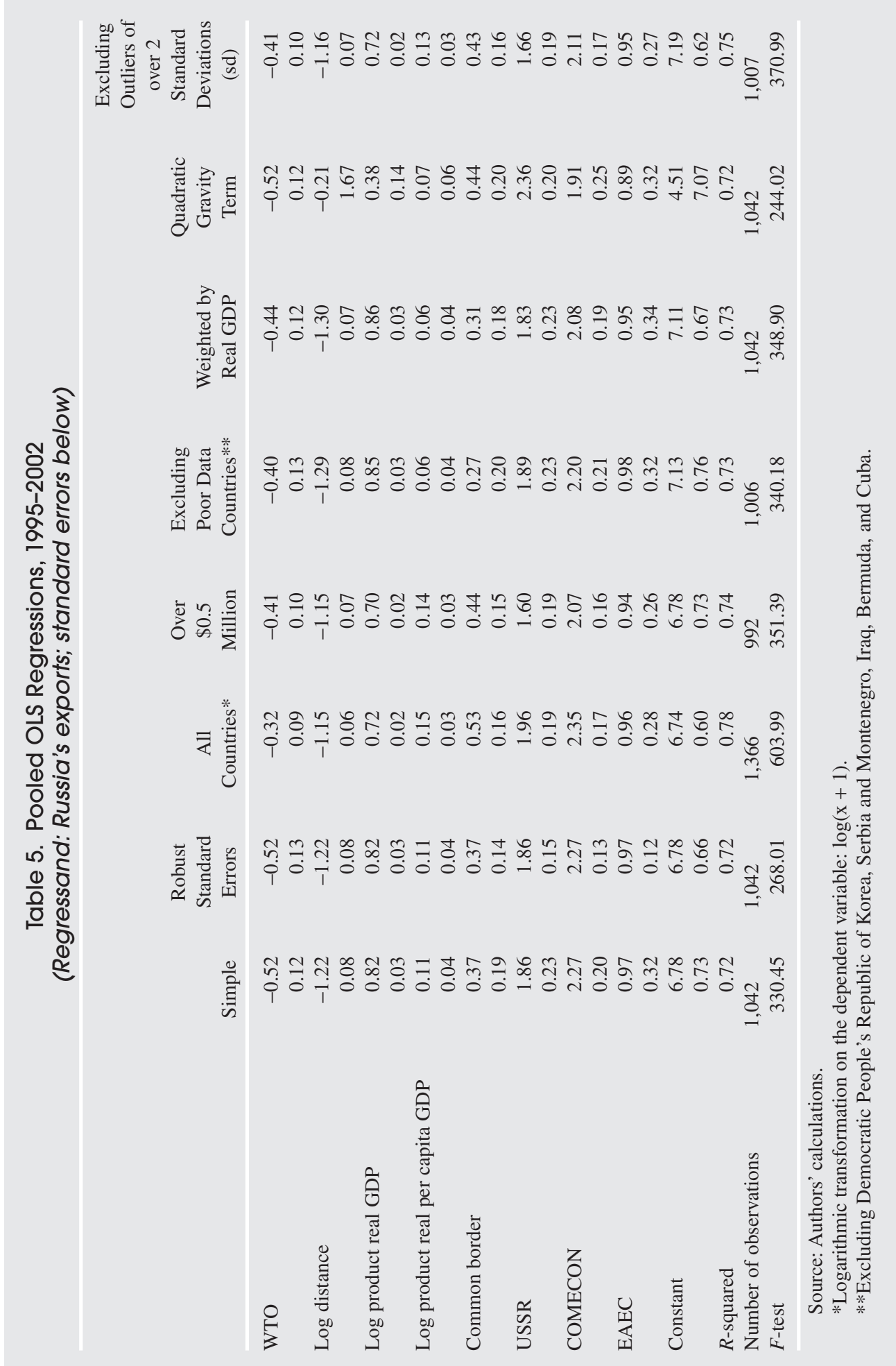




\begin{tabular}{|c|c|c|c|c|c|c|c|}
\hline \multicolumn{8}{|c|}{$\begin{array}{l}\text { Table 6. Regressions with Time Effects, 1995-2002 } \\
\text { (Regressand: Russia's exports; standard errors below. } \\
\text { Coefficients for distance, GDP, and GDP per capita not reported.) }\end{array}$} \\
\hline & Simple & Simple & $\begin{array}{c}\text { All } \\
\text { Countries* }\end{array}$ & $\begin{array}{l}\text { Over } \\
\$ 0.5 \\
\text { Million }\end{array}$ & $\begin{array}{l}\text { Excluding } \\
\text { Poor Data } \\
\text { Countries** }\end{array}$ & $\begin{array}{l}\text { Quadratic } \\
\text { Gravity } \\
\text { Term }\end{array}$ & $\begin{array}{l}\text { Excluding } \\
\text { Outliers } \\
\text { of over } \\
2 \mathrm{sd}\end{array}$ \\
\hline \multirow[t]{2}{*}{ WTO } & -0.54 & -0.51 & -0.44 & -0.47 & -0.41 & -0.52 & -0.47 \\
\hline & 0.12 & 0.12 & 0.09 & 0.10 & 0.13 & 0.12 & 0.11 \\
\hline \multirow[t]{2}{*}{ USSR } & 1.92 & 1.91 & 2.02 & 1.67 & 1.95 & 1.98 & 1.73 \\
\hline & 0.23 & 0.23 & 0.18 & 0.19 & 0.23 & 0.25 & 0.19 \\
\hline \multirow[t]{2}{*}{ COMECON } & 2.30 & 2.10 & 2.40 & 2.13 & 2.23 & 2.39 & 2.16 \\
\hline & 0.20 & 0.21 & 0.16 & 0.16 & 0.21 & 0.20 & 0.17 \\
\hline \multirow[t]{2}{*}{ EAEC } & 0.97 & 0.98 & 0.95 & 0.95 & 0.98 & 0.89 & 0.95 \\
\hline & 0.32 & 0.32 & 0.26 & 0.26 & 0.32 & 0.32 & 0.27 \\
\hline GSP & & $\begin{array}{l}0.64 \\
0.23\end{array}$ & & & & & \\
\hline $\begin{array}{l}\text { Developed } \\
\text { economy }\end{array}$ & & $\begin{array}{r}-0.84 \\
0.23\end{array}$ & & & & & \\
\hline \multirow[t]{2}{*}{ Constant } & 6.55 & 6.24 & 6.23 & 7.06 & 6.92 & 2.83 & 6.90 \\
\hline & 0.73 & 0.76 & 0.58 & 0.61 & 0.76 & 7.05 & 0.62 \\
\hline & 0.72 & 0.72 & 0.78 & 0.74 & 0.73 & 0.72 & 0.75 \\
\hline \multirow{2}{*}{$\begin{array}{l}\text { Number of } \\
\text { observations } \\
F \text {-test }\end{array}$} & 1,042 & 1,042 & 1,366 & 992 & 1,006 & 1,042 & 1,007 \\
\hline & 310.83 & 252.85 & 665.4 & 343.65 & 319.25 & 229.29 & 360.13 \\
\hline $\begin{array}{l}\text { Source: Aut } \\
\text { *Logarithm } \\
\text { **Excludin } \\
\text { and Cuba. }\end{array}$ & $\begin{array}{l}\text { hors' calcu } \\
\text { ic transfor } \\
\text { g Democra }\end{array}$ & $\begin{array}{l}\text { lations. } \\
\text { nation on t } \\
\text { tic People' }\end{array}$ & $\begin{array}{l}\text { he dependent } \\
\text { s Republic of }\end{array}$ & $\begin{array}{l}\text { variable: } \\
\text { Korea, S }\end{array}$ & $\begin{array}{l}\log (x+1) \\
\text { erbia and Mo }\end{array}$ & enegro, Ira & Bermuda, \\
\hline
\end{tabular}

checks, with the WTO coefficient continuing to be significantly negative throughout. In addition to the robustness checks shown in Table 5, we test (in the second column of Table 6) the significance of GSP preferences and of the asymmetry between Russia's exports to the developed and developing economies (through a developed-country dummy). Whereas the WTO coefficient is not affected by these additions, the latter modifications enter with statistically significant coefficients. In particular, the sign on the developed-country dummy is negative, indicating that for some reason Russia's exports to developed countries were "limited" compared with those to other countries, all other things being equal. The sign on the GSP dummy is, as expected, positive.

Table 7 presents augmented robustness checks to the time effects regressions, which do not affect the negative sign of the WTO variable. These include a number of additional controls common in the gravity model literature, such as islands, landlocked areas, the size of the country, and import duties. Additionally, country and sectoral asymmetries are tested, including by dummies for nations that import oil 
Table 7. Robustness Checks, 1995-2002

(Time effects, unless otherwise noted. Regressand: Russia's exports; standard errors below.)

\begin{tabular}{|c|c|c|c|c|c|c|c|}
\hline & 1 & 2 & 3 & 4 & 5 & 6 & $7 *$ \\
\hline \multirow[t]{2}{*}{ WTO } & -0.57 & -0.41 & -0.41 & -0.43 & -0.40 & -0.35 & 0.20 \\
\hline & 0.12 & 0.14 & 0.14 & 0.13 & 0.13 & 0.16 & 0.19 \\
\hline \multirow[t]{2}{*}{ USSR } & 1.97 & 1.98 & 2.00 & 1.17 & 1.31 & 0.94 & \\
\hline & 0.22 & 0.22 & 0.22 & 0.26 & 0.24 & 0.34 & \\
\hline \multirow[t]{2}{*}{ COMECON } & 2.39 & 2.37 & 2.25 & 1.96 & 2.21 & 1.70 & \\
\hline & 0.20 & 0.20 & 0.21 & 0.21 & 0.21 & 0.28 & \\
\hline \multirow[t]{2}{*}{ EAEC } & 1.29 & 1.30 & 1.26 & 1.11 & 0.96 & 1.27 & \\
\hline & 0.32 & 0.32 & 0.32 & 0.31 & 0.32 & 0.38 & \\
\hline \multirow[t]{2}{*}{ Landlocked } & -0.28 & -0.26 & -0.25 & -0.29 & -0.39 & -0.46 & \\
\hline & 0.14 & 0.14 & 0.14 & 0.14 & 0.14 & 0.16 & \\
\hline \multirow[t]{2}{*}{ Island } & -0.10 & -0.10 & 0.01 & -0.16 & 0.05 & -0.36 & \\
\hline & 0.17 & 0.17 & 0.18 & 0.18 & 0.17 & 0.22 & \\
\hline \multirow[t]{2}{*}{ Log area } & -0.25 & -0.26 & -0.24 & -0.20 & -0.20 & -0.21 & \\
\hline & 0.04 & 0.04 & 0.04 & 0.04 & 0.04 & 0.05 & \\
\hline \multirow[t]{2}{*}{ GSP } & & & 0.55 & 0.16 & 0.84 & 0.12 & \\
\hline & & & 0.24 & 0.24 & 0.23 & 0.29 & \\
\hline \multirow[t]{2}{*}{ Developed economy } & & & -0.43 & -0.50 & -0.86 & -0.64 & \\
\hline & & & 0.24 & 0.24 & 0.25 & 0.29 & \\
\hline \multirow[t]{2}{*}{ Oil } & & & & 1.03 & & 1.18 & \\
\hline & & & & 0.16 & & 0.21 & \\
\hline \multirow[t]{2}{*}{ Steel } & & & & & 1.06 & & \\
\hline & & & & & 0.16 & & \\
\hline \multirow[t]{2}{*}{ Import duties } & & & & & & -0.07 & \\
\hline & & & & & & 0.11 & \\
\hline \multirow[t]{2}{*}{ GATT-94 } & & -0.32 & -0.33 & -0.21 & -0.32 & -0.14 & \\
\hline & & 0.13 & 0.13 & 0.13 & 0.13 & 0.15 & \\
\hline \multirow[t]{2}{*}{ Constant } & 8.13 & 7.89 & 7.42 & 7.09 & 7.45 & 7.76 & 31.70 \\
\hline & 0.77 & 0.77 & 0.80 & 0.79 & 0.78 & 1.03 & 6.41 \\
\hline$R$-squared: overall & 0.73 & 0.73 & 0.74 & 0.75 & 0.75 & 0.75 & 0.92 \\
\hline Number of observations & 1,042 & 1,042 & 1,042 & 1,042 & 1,042 & 795 & 1,042 \\
\hline$F$-test & 242.39 & 223.83 & 192.92 & 189.79 & 190.56 & 145.00 & 58.19 \\
\hline
\end{tabular}

Source: Authors' calculations.

Notes: Coefficients for distance, GDP, and GDP per capita not reported.

*Fixed-effects regression with country dummies included.

and steel from Russia. Accounting for these specificities may be important, given the somewhat skewed structure of Russia's exports of those products and because of pronounced trade idiosyncrasies in those sectors (i.e., large trade restrictions for steel). Incidentally, both the oil and steel dummies have large, positive, and significant coefficients. Finally, a variable, GATT-94, has been included to measure the impact for those countries that were the founders of the WTO, since they could be seen as a core group of economies with a long-term commitment to multilateral trade liberalization. Interestingly, the coefficient on this term is significantly negative, and its inclusion does not have much impact on the coefficient of the broader 
WTO variable. ${ }^{9}$ In addition, we have run several regressions by adding a lagged dependent variable, which have also yielded a negative WTO coefficient, although more weakly significant (at 5-20 percent, depending on the exact specification).

We also attempted to infer from time variation in the data, although this exercise was somewhat limited by modeling and data problems. The last column of Table 7 contains estimates of a country fixed-effects regression ${ }^{10}$ with countryspecific dummies (with standard adjustments to avoid the overidentification problem). In such regressions, all time-invariant variables (distance and most regional and country dummies) are effectively subsumed into the constant term, thereby exploiting only the variation among four variables: total and per capita GDP, WTO, and exports. The regression essentially addresses a "within" question: What does joining the WTO do to a country's imports from Russia? The positive (albeit not significant at the 10 percent level) coefficient on the WTO dummy weakly suggests, in line with intuition, that the countries that joined the WTO over the sample period actually favored Russian exports at the margin. However, this result has to be taken with caution, because (1) the time period of analysis is short and the number of observations fairly small; and (2) important "control" variables (regional dummies) and the distance variable drop out from the analysis, which may modify the relationship within this "aborted" gravity model.

\section{Discussion of Results}

The main result is that within a well-fitting gravity model for Russia, the WTO coefficient is negative and statistically significant in the baseline cross-section and most panel data regressions. On this basis, the structure of Russia's trade remains in some sense "suboptimal" or "different" compared with the benchmark offered by the gravity model, in that it trades "too little" with the WTO members and/or "too much" with non-WTO members. This may not seem surprising, given that a good portion (but by no means all) of non-WTO members are former socialist economies, with significant historical and systemic ties with Russia. However, these results are somewhat surprising, since we control for these specificities through various regional dummy variables, which are themselves intuitive, with large coefficients, and highly significant.

This basic result applies to the 1995-2002 period on average but does not yet indicate how this bias evolved over time. First, judging from Table 4, the WTO coefficient in independent cross-section regressions was negative, albeit volatile, in 1996-98 and stabilizing within a remarkably narrow range around -0.55 in 1999-2002. This indicates that the extent of anti-WTO trade bias appeared to be

\footnotetext{
${ }^{9} \mathrm{~A}$ "between-effects" panel estimation yielded an even larger absolute estimate of the WTO coefficient, in the range of minus 0.7 to minus 0.9 , with the coefficient being robustly statistically significant. Otherwise, results were similar to those of the time effects regression.

${ }^{10} \mathrm{~A}$ random-effects regression seems less appropriate, given that its underlying assumption-that unobserved individual heterogeneity is uncorrelated with the included variables-seems somewhat heroic in the case of our model (for example, heterogeneity with respect to the GDP variable). In any case, the results from the random-effects regression showed a negative coefficient on the WTO variable, albeit small and insignificant.
} 
roughly constant over the sample period. Second, the fixed-effects regression with country-specific dummies actually suggests that Russia's trade with the WTO was encouraged at the margin, since some 30 countries that joined the WTO after 1995 tended to favor Russian exports, all other things being equal (Table 3). This may be a consequence of the general trade-liberalizing measures that these countries undertook in the process of WTO accession and thus may be consistent with the overall WTO positive spillover effect found by Subramanian and Wei (2003). Still, our regressions show only a limited "within" effect during 1995-2002 and thus do not reject the possibility of a "trap" or some persistence of an anti-WTO equilibrium.

In sum, the highlighted bias concerns the trade structure in terms of levels, while the evidence on the direction of change is largely inconclusive. Numerically, the value of the WTO coefficient in most regressions suggests that, in the long run, Russia exports on average at least one-third less $[\exp (-0.4)-1]$ to members of the WTO than to all of its trading partners. These are very large estimates, implying potentially huge trade costs of nonmembership in the WTO, subject to a number of qualifications, which will be investigated below.

\section{Factors Behind the Regression Results}

Why does the structure of Russia's trade differ from that suggested by the gravity model? Clearly, various factors could account for Russia's particular trading pattern, ranging from statistical and historical reasons to more substantive economic and policy issues. We briefly review key arguments below; more details can be found in Lissovolik and Lissovolik (2004).

First, Russia's exports may be constrained by restrictions imposed by its WTO trading partners, either because these do not enjoy the full benefits from the trade liberalization rounds, or owing to barriers-formal or informal-levied by individual WTO members. WTO member countries may impose these barriers on nonmembers more readily than on members, because the former cannot retaliate, because they do not belong to the WTO's dispute settlement bodies, or for other reasons.

To gauge the influence of trade barriers on our regression results, we have included a separate GSP term in the regressions (Table 7); it carries the expected positive sign, but has only a marginal impact on the significance of the WTO sign. In addition, we have controlled for the level of explicit import duties (Table 7); the sign is, as expected, negative, but the economic and statistical significance of the coefficient is marginal. These weak results are not surprising, given that dummies are only rough proxies for policies, but this may also suggest a role for "implicit" and "microlevel" restrictions, such as antidumping actions, or the probability of recourse to them.

Regarding the sensitivity of our results to these de facto restrictions (including implicit trade barriers), we introduced sectoral dummies within the regressions (Table 7), focusing on two benchmark export commodities that are starkly different from the point of view of trade restrictions: steel and oil. As expected, both dummies appear highly significant and have positive coefficients. A steel importer dummy, which controls for a sector in which trade restrictions (explicit and implicit) 
are prevalent, reduces the size of the coefficient on the WTO variable; while an oil importer dummy - with no perceptible trade restrictions on the part of importersincreases the absolute size of the negative coefficient. ${ }^{11}$ These results suggest a positive link between the anti-WTO bias and restrictions on Russia's exports. However, the evidence is only suggestive, since the changes in the WTO coefficient are fairly small.

Second, the export pattern may have been influenced by Russia's domestic export restrictions. While most of Russia's export duties were gradually dropped by mid-1996, some duties were introduced or reintroduced in 1999-2000. There is at least some evidence pointing to the role of these domestic export restrictions in generating the gravity model's negative WTO coefficient. In the cross-section results of Table 4, the significance of the WTO variable becomes much lower in 1997 and essentially breaks down in 1998, when domestic export restrictions were minimal. ${ }^{12}$

Third, the negative sign on the WTO variable may be connected to Russia's excessively good bargaining position vis-à-vis some non-WTO members, which may be labeled as "relatively small and dependent economies." However, the coefficient on the real GDP in the regressions is positive and-at just below unityconsistent with those from other gravity model applications. This, all other things being equal, suggests that there is nothing special in Russia's trade with smaller countries.

Fourth, despite its good fit, the gravity model is susceptible to specification problems. These may include (1) insufficient control for multilateral resistance (Anderson and van Wincoop, 2003); (2) endogeneity bias (countries with substantial trade with Russia are less interested in WTO entry); (3) simultaneity bias (political preferences or other factors pushing some countries toward Russia and away from the WTO at the same time); and (4) omitted variables that tilt Russia's trade toward particular countries (including insufficient quality of Russia's manufacturing products). We explored these issues to some extent in Lissovolik and Lissovolik (2004) and found no clear evidence of these problems, either on economic or statistical grounds. For example, the GATT-94 coefficient that controls for the established WTO members (and is not affected by endogeneity) is significantly negative in all specifications of the gravity model.

We also have checked the sensitivity of our results to country groupings more generally. Thus, industrial countries - all of which were WTO members during the sample period - appear to be particularly nonreceptive to Russia's exports. As we can see from Table 7, a dummy for those countries is significant in most of our benchmark regressions, and always with a negative sign. If we split the WTO dummy into developed- and developing-country dummies, the developed-country dummy has a larger absolute value of almost -1.1 , compared with the developing country WTO dummy of -0.55 , with both being significant. Regarding the sensi-

${ }^{11}$ Oil, with the role of pipeline infrastructure in generating export inertia, may not be a perfect example, but a fair portion of Russia's oil exports (by sea) can be redirected at the margin.

${ }^{12} \mathrm{At}$ the same time, there could be an alternative explanation based on our first hypothesis (WTO countries' restrictions on Russia's exports). Russia's declining export performance in 1997-98 may have been caused by the concurrent global crisis, with some preset import restrictions becoming less binding because of the contraction in world trade. 
tivity of the regression results to individual country observations, we compared leverage against normalized squared residuals for cross-section regressions on annual means that were reported in the last two columns of Table 4. The leverage measure indicates the extent to which an observation is influential for the regression results, while greater residuals denote outliers. Observations high in leverage (Belarus, Kyrgyz Republic, etc.) are not the ones that are large outliers (Gabon, Botswana, and the Democratic Republic of the Congo). Excluding the most important outliers or leveraged observations does not alter the results with respect to the sign and the significance of the WTO dummy (Table 8).

This list of reasons is by no means exhaustive. Still, the model's outcomes and manipulations lend some credence to the link between export restrictions, both from outside and within Russia, and the "anti-WTO tilt" in Russia's trade. In any case, the combination of the "overall" and "within" results reinforces a lack of broader evidence that established WTO members have been as receptive as others to Russia's exports.

\section{Implications for Russia's WTO Accession}

Assuming that the gravity model results can proxy Russia's export structure following its WTO entry, one may project Russia's putative trade developments in a "postentry" world. The numerical coefficients in our regressions imply that, in the long run, Russia's exports to WTO members could expand by a very large amount-

Table 8. OLS Cross-Country Regression on Annual Means, 1995-2002 (Coefficients on constant and border not reported)

\begin{tabular}{|c|c|c|c|c|}
\hline & \multicolumn{2}{|c|}{ Without Outliers* } & \multicolumn{2}{|c|}{ Without High-Leverage Observations** } \\
\hline Number of observations & \multicolumn{2}{|c|}{160} & \multicolumn{2}{|c|}{164} \\
\hline $\mathrm{F}(8,151)$ & \multicolumn{2}{|c|}{101.90} & \multicolumn{2}{|c|}{70.41} \\
\hline Prob $>\mathrm{F}$ & \multicolumn{2}{|c|}{0.00} & \multicolumn{2}{|c|}{0.00} \\
\hline Adjusted $R$-squared & \multicolumn{2}{|c|}{0.84} & \multicolumn{2}{|c|}{0.75} \\
\hline Exports (dep. var.) & Coefficient & Standard error & Coefficient & Standard error \\
\hline WTO96 & -1.16 & 0.28 & -0.97 & 0.35 \\
\hline EAEC & 1.10 & 0.80 & - & - \\
\hline COMECON & 2.20 & 0.47 & 2.28 & 0.61 \\
\hline USSR & 1.82 & 0.56 & 1.95 & 0.73 \\
\hline GDP per capita & 0.20 & 0.08 & 0.15 & 0.10 \\
\hline Distance & -1.30 & 0.19 & -1.35 & 0.25 \\
\hline GDP & 0.98 & 0.06 & 0.99 & 0.07 \\
\hline
\end{tabular}


according to most regressions, by around 50 percent. ${ }^{13} \mathrm{~A}$ major issue is the extent to which this correction of trade diversion would occur through export expansion as opposed to reorientation. In the latter case, there would be a substitution effect, and a smaller increase in Russia's exports to the WTO countries would suffice to align its export structure. In all likelihood, both the expansion and substitution effects would be present, but a precise configuration could not be modeled without a more detailed structure. Generically, though, there has to be some export expansion. In particular, if the economic reasons for our underlying results are trade restrictions of any type, it is unlikely that the trade-off between exportables and nontraded goods would be unaffected after the restrictions on exports have been relaxed.

In any case, our estimates indicate an asymptotic upper bound of the long-run effect. In the short run, the WTO-related export expansion may be further limited, given the evidence that, in some key export-oriented sectors (such as metals), Russia's capacity utilization rate has approached fairly high levels. In this situation, a further export expansion hinges on substantial investment and could be delayed.

Another caveat with respect to future projections is our narrow interpretation of the WTO membership dummy as the main causal channel in the model. The WTO variable may be proxying other factors than membership; for example, Russia's recognition as a market economy for antidumping purposes. Russia obtained this status with most major countries by late 2002, without becoming a WTO member. Thus, the magnitude of the WTO dummy should be interpreted not so much as a precise elasticity but more as an indication of the role of this broad channel. Note that with our data set ending in 2002, the market status argument could not be checked directly.

\section{Implications for WTO-Related Multilateral Studies}

In what way can the negative WTO result for Russia be generalized? The apparent persistence of an anti-WTO bias in Russia's trade structure may call into question the WTO's trade-promoting role and relevance, including the spillover effects emphasized by Subramanian and Wei (2003). But this reasoning leads to an uneasy puzzle, since WTO membership in general and for particular countries is considered important, not only in academic and public circles but also in practical negotiations, decisions, and outcomes. ${ }^{14}$ We believe that our results point to why the WTO may be relevant. While our analysis cannot prove or disprove the insights of Rose (2004), it suggests that the situation may be more complex and that focusing on averages may be insufficient for understanding the WTO's exact role and the associated policy issues.

In particular, we would argue that three asymmetries (in addition to those emphasized by Subramanian and Wei, 2003) may be important in generalizing

\footnotetext{
${ }^{13}$ Our baseline assumption is that, in the long run, the gravity model coefficient on the WTO would approximate zero, which is roughly consistent with the multilateral results of Rose (2004).

${ }^{14}$ The recent debates on the WTO's role in job outsourcing in industrialized countries and China's export expansion are cases in point.
} 
insights from our results. First, the asymmetry between members and nonmembers should be studied more carefully. Our negative WTO result for Russia's trade pattern may crucially depend on Russia being a nonmember country. It is thus possible that a strong anti-WTO bias for some country combinations is (largely) offset by pro-WTO results for other combinations, even if one controls for the usual gravity factors.

The second type of asymmetry is between the policy response to larger and smaller countries, as it may be quite logical that larger countries like China or Russia may be generating more concern over their export potential and, hence, may face more restrictions from third countries. This may explain why our Russiacentered results are more significant than Rose's (2004) multilateral average for nonmembers.

Third, there are asymmetries based on political and systemic alliances that affect WTO members and nonmembers differently and at the same time influence the direction of trade. As an example, a stark division of the world into (pro-)socialist (largely non-WTO) and capitalist (largely WTO) camps for much of the postwar period may substantially bias the results of the long-term models and may have contributed to the emergence of localized centers of gravity. These issues may not be fully accounted for in gravity models, and a country-centered model seems better suited than multilateral gravity models to include essential policy-cum-political dummies. For this purpose, the role of country-specific fixed-effects results becomes more important, and the results are more positive for the WTO's tradepromoting role both in the multilateral and the Russia-centered framework. ${ }^{15}$

Interestingly, our evidence on the specific asymmetry between developed and developing countries emphasized by Subramanian and Wei (2003) differs from that of the authors. While they linked the lack of trade openness within the WTO to developing countries, Russia's exports to the industrialized WTO members appeared to be disadvantaged to the same or even greater extent than those to developing WTO countries. This in part reflects our "within" result that Russian exports seemed to benefit (albeit slightly) from trade liberalization of new WTO members, all of which were either developing or transition countries. Thus, our results imply that WTO membership may be particularly important for access to developed country markets by current nonmembers. ${ }^{16}$

More generally, our results point to the possibility of a domino effect in the expansion of WTO membership that is akin to the similar effect estimated in the operation of regional trade arrangements (RTAs) (see Sapir, 2001). The driving force behind the operation of the domino effect is the costs of nonmembership, which are countered by applying for membership in an RTA. As in any RTA,

\footnotetext{
${ }^{15}$ Still, the evidence for a positive WTO impact in fixed-effects regressions is fairly weak, partly because the coefficient captures a shorter-run "within" effect, as opposed to the longer-run "between" effect of the OLS regressions.

${ }^{16}$ This conclusion would run counter to Rose's (2004) point that developed WTO country members indiscriminately extend trading preferences to nonmembers; instead, it would support a study by UNCTAD (2004) arguing that the world's poorest countries are receiving only limited benefits from preferential trade schemes designed to help them, because of gaps in coverage and restrictive rules of origin.
} 
incomplete WTO membership creates a wedge between members and nonmembers that may turn out to be costly for the latter.

In sum, we are more comfortable with this complex view, which also goes some way toward explaining the WTO "irrelevance puzzle." Thus, the WTO appears relevant and may have inner trade-promoting features that appear to average out in the simple gravity comparisons. At the same time, we would not want to be too categorical on this point, since Russia's specific circumstances as a nonmember and the short period of analysis weaken comparability with the long-term multilateral studies.

\section{Concluding Remarks}

We show that Russia's export structure, after controlling for gravity effects and several country- and region-specific factors, was tilted significantly away from WTO members in 1995-2002. The evidence of trade reorientation toward the predicted pattern during the same period is quite weak, as it affects only new WTO members and does not apply to Russia's exports to advanced economies. We reason that these results may be at least partially related to the external and possibly domestic constraints on Russia's exports, which, in turn, depend on Russia's continued nonmembership in the WTO. This would suggest that Russia's WTO accession may redirect and/or expand Russia's exports substantially, although possibly only in the very long term. While it cannot be fully ruled out that Russia's historical, cultural, or other idiosyncratic factors may bias our results, various methods and controls for most country- and region-specific observable effects did not eliminate the significance of the negative influence of the WTO variable.

Our findings are related to two strands of WTO-related research: global and Russia-specific. Globally, this is an interesting case study within a general debate between Rose $(2002,2004)$ and other authors on the extent of the WTO-induced gains from trade. Our results suggest that the WTO impact is quite relevant but likely combines trade promotion among members with some implicit trade frictions between members and nonmembers, while nonmembers may have additional reasons to trade with each other that cannot be captured by the gravity model. At the same time, our analysis does not formally prove or disprove the multilateral model insights, and further rigorous testing is required.

With respect to Russia-specific issues, our results suggest tangible long-term trade gains for Russia from its WTO accession, not least because of the highlighted friction between members and nonmembers. Although the time profile of Russia's gains is uncertain, waiting to join the WTO is likely not an attractive option, given the weak pace of the underlying reorientation to date. While generalizations may be misleading, China's early experience seems to (albeit casually) confirm the WTO membership's strong effect on exports. ${ }^{17}$ It also should be cautioned that the empirical model is a simplification, in that it treats WTO accession

\footnotetext{
${ }^{17}$ In 2002-03, according to the IMF Direction of Trade Statistics, China's annual growth in exports and net foreign direct investment was 27 percent and 14 percent, respectively, compared with corresponding annual averages of 17 percent and 7 percent over the decade prior to its WTO entry.
} 
as a binary choice (accession or nonaccession), while the reality is more complicated, as the effect of Russia's WTO accession obviously depends on the outcome of the negotiations.

Still, at the very least, we have shown that (1) there is an underlying bias in Russia's trade structure that may need to be addressed, and (2) entering the WTO appears to be the most logical way to address it. Regarding current trade policy, Russia should, through WTO membership, benefit from a stronger focus on ensuring uniformity and a level playing field across regional trading patterns. The sheer size and diversity of the country favor trade integration via WTO membership rather than through regional arrangements. Also, Russia's entry would make the WTO nearly universal, thereby possibly giving a multilateral boost to global trade.

\section{Table A.1. Chronology of Russia's WTO Accession Process}

Stages of Accession

\section{Request for accession}

Memorandum on the foreign trade regime to be submitted to the working party

Questions and replies: Submission of the memorandum followed by questions from the members of the working party and answers from Russia

Working party multilateral negotiations to determine the general conditions of accession, including commitments to observe WTO rules and the length of transitional periods necessary to ensure their implementation

Working party bilateral negotiations. Each accession working party makes decisions by consensus; thus, Russia must reach an agreement with each member of the working party.

The accession package:

The results of the negotiations are reflected in three documents that form the accession package:

- Report of the working party that contains a summary of proceedings and conditions of entry.

-Protocol of accession. This document provides all the general terms and conditions of membership, including the areas of the administration of trade regime, nondiscrimination, the use of nontariff measures, and so on.

- Schedules of market access commitments in goods and services that reflect the agreements reached with the members of the working party.

\section{3}

March 1994, May 2001, November 2001

June 1995, June 1996

20 meetings of the working party in 1995-2003

Agreements on market access concluded with several countries, including with the European Union in May 2004.

Draft working party reports

(March 2002, November 2002,

May 2003)

Source: Authors' elaboration based on www.wto.ru. 


\section{Table A.2. Definitions of Variables}

Variable

Log exports

Log turnover

Log product GDP

Log product GDP per capita

Log distance

COMECON

WTO

USSR

EAEC

Developed

GSP

Island

Landlocked

Log product area

Oil

Steel

GATT-94

Import duties

\section{Definition}

Natural logarithm of Russia's annual exports in 1995-2002 deflated by U.S. CPI

Natural logarithm of Russia's annual trade turnover in 1995-2002 deflated by U.S. CPI

Natural logarithm of the product of Russia's GDP and that of Russia's trade partners in 1995-2002 deflated by U.S. CPI

Natural logarithm of the product of Russia's GDP per capita and that of Russia's trade partners in 1995-2002 deflated by U.S. CPI

Natural logarithm of the distance from Moscow to the capitals of Russia's trade partners

Dummy variable $(1=$ former COMECON member (East Germany excluded), $0=$ not a former member of COMECON)

Dummy variable $(1=$ member of the WTO, $0=$ not a member of the WTO)

Dummy variable ( $1=$ former member of the USSR, $0=$ not a former member of the USSR)

Dummy variable $(1=$ member of EAEC, $0=$ not a member of EAEC)

Dummy variable ( $1=$ developed country, $0=$ developing country)

Dummy variable ( $1=$ trading partner accords GSP treatment to Russia, $0=$ trading partner does not accord GSP treatment to Russia)

Dummy variable ( $1=$ island country, $0=$ non-island country)

Dummy variable ( $1=$ landlocked country, $0=$ non-landlocked country)

Natural logarithm of the product of Russia's area (in sq. km) and that of Russia's trade partners

Dummy variable (1=importer of oil from Russia in 1995, $0=$ all other countries)

Dummy variable ( $1=$ importer of steel from Russia, $0=$ all other countries)

Dummy variable ( $1=$ member of the WTO as of January 1,1995 ; $0=$ all other countries)

Natural logarithm of the average import tariff in Russia's trading partners

Source: Authors' calculations.

\section{REFERENCES}

Alekseev A., N. Tourdyeva, and K. Yudaeva, 2003, "Estimation of Russia's Trade Policy Options with the Help of the Computable General Equilibrium Model," CEFIR Working Paper No. 42 (Moscow: Center for Economic and Financial Research). Available via the Internet: www.cefir.org.

Anderson, J., and E. van Wincoop, 2003, "Gravity with Gravitas: A Solution to the Border Puzzle," American Economic Review, Vol. 93 (March), pp. 170-92.

Berglöf, E., and others, 2003, The New Political Economy of Russia (Cambridge, Massachusetts: MIT Press). 
Bergstrand, J.H., 1985, “The Gravity Equation in International Trade: Some Microeconomic Foundations and Empirical Evidence," Review of Economics and Statistics, Vol. 67 (3), pp. 474-81.

Blanchard, O., and M. Kremer, 1997, "Disorganization," Quarterly Journal of Economics, Vol. 112 (November), pp. 1091-126.

Daviddi, R., and E. Espa, 1996, "The Liberalization of the Foreign Trade of the Russian Federation and the Accession to the WTO," in Russia and the World Economy, ed. by G. Mureddu and M. T. Salvemini (Rome: La Sapienza).

Dean, J., and I. Eremenko, 2003, "Will WTO Membership Really Improve Market Access for Ukrainian Exports?" paper presented at the 37th annual meeting of the Canadian Economics Association, Ottawa, May.

Elborgh-Woytek, K., 2003, "Of Openness and Distance: Trade Developments in the Commonwealth of Independent States, 1993-2002," IMF Working Paper 03/207 (Washington: International Monetary Fund).

Granville, B., 1995, The Success of Russian Economic Reforms (London: Royal Institute of International Affairs).

Greenaway, D., and C. Milner, 2002, "Regionalism and Gravity," Leverhulme Centre Research Paper No. 2002/20 (Nottingham, England: University of Nottingham, Leverhulme Centre).

Gros, D., and A. Steinherr, 1995, Winds of Change: Economic Transition in Central and Eastern Europe (London; New York: Longman).

Hufbauer, G.C., and B. Oegg, 2003, "The Impact of Economic Sanctions on U.S. Trade: Andrew Rose's Gravity Model," International Economic Policy Briefs No. PB03-4 (Washington: Institute for International Economics).

International Monetary Fund, Direction of Trade Statistics, 1995-2003.

Linnemann, H., 1966, An Econometric Study of International Trade Flows (Amsterdam: North-Holland).

Lissovolik, B., and Y. Lissovolik, 2004, "Russia and the WTO: The 'Gravity' of Outsider Status," IMF Working Paper 04/159 (Washington: International Monetary Fund).

Lissovolik, Y., and N. Liventsev, 2002, Actualnyye Problemy Prisoyedineniya Rossii k VTO (Moscow: Ekonomika).

Matyas, L., 1997, "Proper Econometric Specification of the Gravity Model," The World Economy, Vol. 20 (May), pp. 363-68.

Owen, D., and D. Robinson, eds., 2003, Russia Rebounds (Washington: International Monetary Fund).

Rose, A.K., 2002, "Do We Really Know That the WTO Increases Trade?" NBER Working Paper No. 9273 (Cambridge, Massachusetts: National Bureau of Economic Research).

_ 2004, "Do We Really Know That the WTO Increases Trade?" American Economic Review, Vol. 94 (March), pp. 98-114.

— 2005. Available via the Internet: http://faculty.haas.berkeley.edu/arose/.

Russian Academy of Sciences and the National Investment Council (RAS), 2002, The Implications of Russia's Accession to the WTO for the National Economy (Moscow: RAS).

Sapir, A., 2001, "Domino Effects in Western European Regional Trade, 1960-92," European Journal of Political Economy, Vol. 17 (June), pp. 377-88.

Subramanian, A., and S.J. Wei, 2003, "The WTO Promotes Trade, Strongly but Unevenly," IMF Working Paper 03/185 (Washington: International Monetary Fund). 
Tarr, D., J. Jensen, and T. Rutherford, 2002, "Economy-Wide and Sector Effects of Russia's Accession to the WTO," paper prepared for the New Economic School Tenth Anniversary Conference, "The State of Economics and of Transition," Moscow, December.

UNCTAD, 2004, "Trade Preferences for LDCs: An Early Assessment of Benefits and Possible Improvements" (UNCTAD/ITCD/TSB/2003/8). Available via the Internet: http://www.unctad. org/Templates/webflyer.asp?docid=4293\&intItemID=1397\&lang=1\&mode=highlights.

van Selm, B., 1997, The Economics of Soviet Break-Up (London: Routledge).

Wang, Z.K., and L.A. Winters, 1992, “The Trading Potential of Eastern Europe," Journal of Economic Integration, Vol. 7 (Autumn), pp. 113-36. 